\title{
RSI Calculation
}

\section{Oi Ka Ka ${ }^{1}$}

${ }^{1}$ Affiliation not available

September 12, 2020

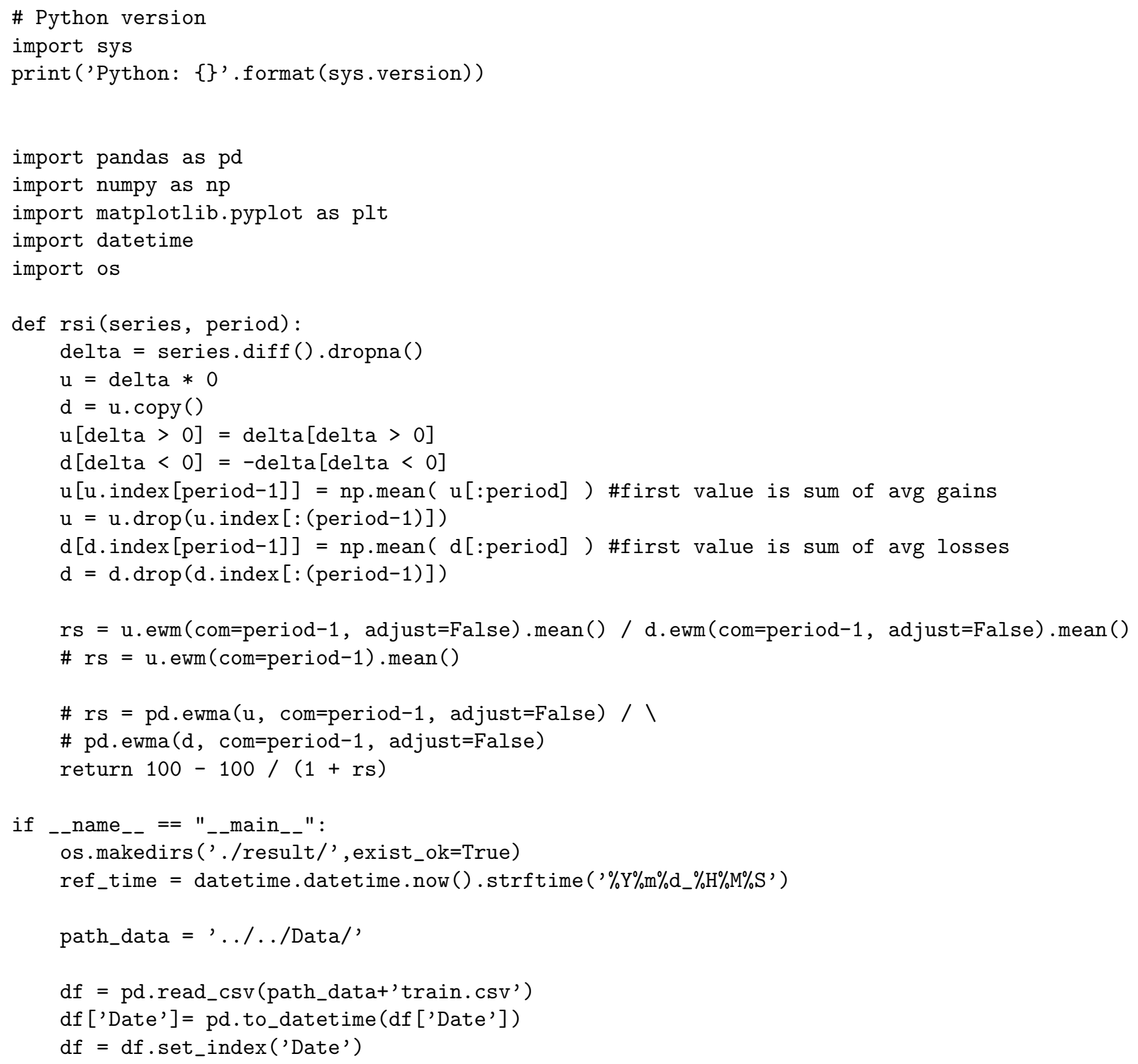




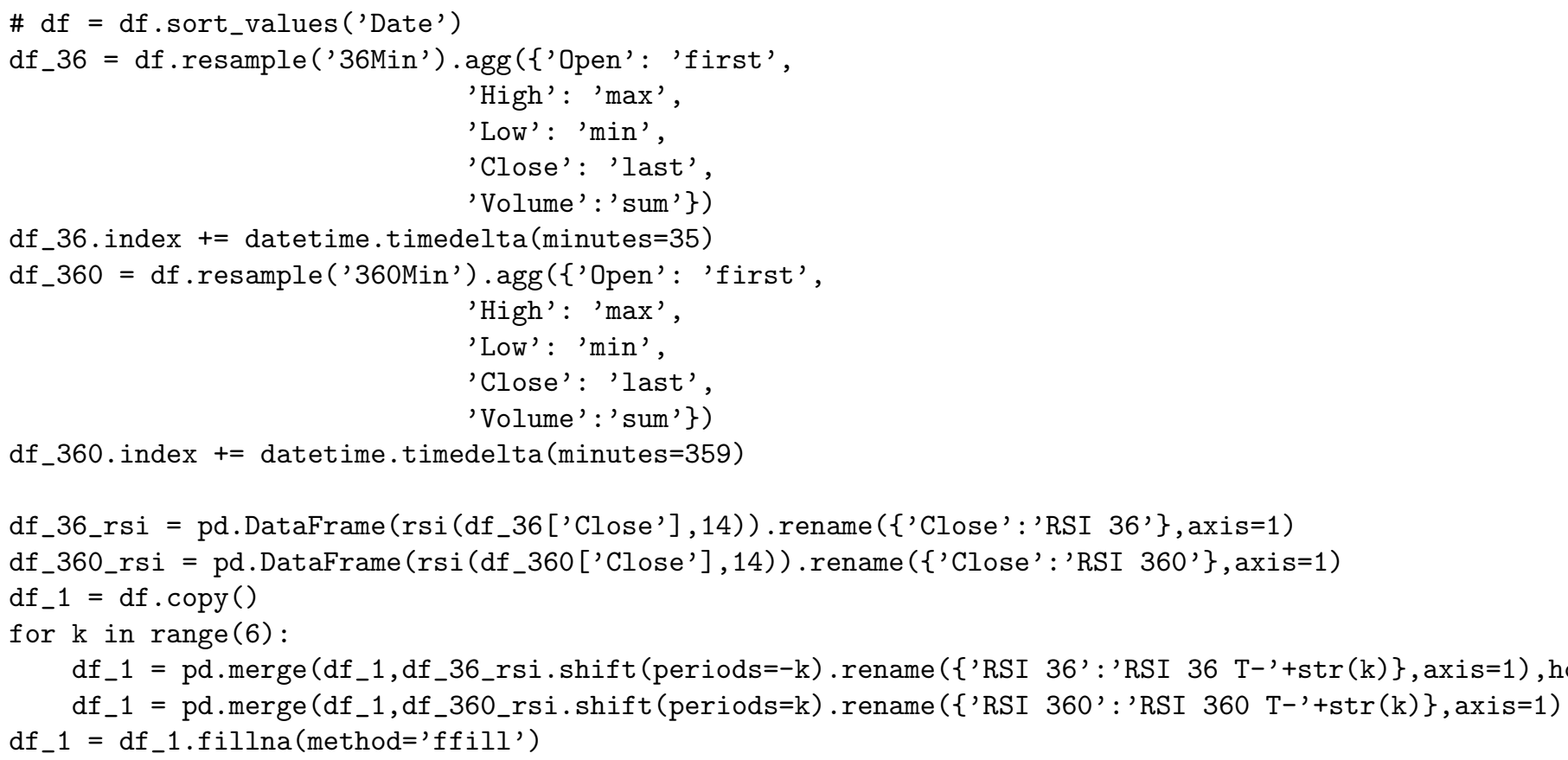

